\title{
The nexus between tourism development and economic growth in Eastern Indonesia: a panel VECM approach
}

\author{
Amaluddin \\ Development Economics Department, Faculty of Economics and Business, \\ Universitas Pattimura, Indonesia \\ Correspondence author email: amaluddin001@gmail.com
}

\begin{abstract}
The empirical nexus between tourism development and economic growth have been widely examined, however, the empirical results generally produce diverse conclusion and often debated. The purpose of this empirical study is, firstly, to investigate and analyze the dynamic relationship between tourism sector development and economic growth both in the short and long run. Secondly, to examine the direction of causality between tourism development and economic growth in Eastern Indonesia over the period 2010-2017. This study employed a panel vector error correction model (PVECM) for the quantitative analysis approach from panel data of 12 provinces in eastern Indonesia. The empirical findings of this study were: 1) In the long run, the relationship between tourism development and economic growth supported the feedback causality hypothesis where changes and expansion in the tourism development affect economic growth and increasing economic growth have an impact on the expansion of the tourism sector (bi-directional causality). 2) The empirical findings corroborated the growth-led tourism hypothesis in the short run which argues that the achievements of economic growth affect the expansion of tourism development. In the short run, this empirical study only found a one-way causality running from economic growth to tourism development.
\end{abstract}

Keywords: Causality, Economic growth, PVECM, Tourism development,

JEL Classification: O11, Z32

\section{INTRODUCTION}

In the last decades, the tourism sector has a strategic role and provided significant growth along with the dynamics of the national development paradigm that is more oriented to the development of the service and industry sector. The development of the tourism sector is very promising so that it is expected to become a leading sector in Indonesia's development. In 2017, the contribution of the tourism sector to the country's foreign exchange revenues reached USD 16.8 billion while its contribution to GDP and employment was around $18.5 \%$ and 12.5 million people. Evidence of Indonesia's success in the development of the tourism industry can be evaluated from the growth trend of the tourism sector with an indicator of the number of tourist arrivals increasing from year to year, especially foreign tourists. In 2010, the number of foreign tourist arrivals was 7 million people, then in 2017 increased to as many as 14 million people or experienced an average growth of $10.56 \%$ per year with the highest growth in 2017 of 
$21.88 \%$, whereas in the same year national economic growth only grew by $5.07 \%$. (BPS, 2019).

Indonesian tourism is targeted to be one of the best destinations in the world. Steps to become a world-class tourism destination have been carried out, among others, through the Wonderful Branding Country Indonesia. However, one of the important issues in the development of Indonesia's tourism sector is the low competitiveness caused by the lack of availability of infrastructure and tourism investment both government and private sector, especially in Eastern Indonesia, indicating that there is still a development gap between the Western Indonesia and Eastern Indonesia. In 2011, the provinces in eastern Indonesia were able to contribute to economic growth of $4.44 \%$, then in 2017 an increase of $5.65 \%$, with an average economic growth of $6.48 \%$ per year. In the same period, the number of foreign tourist arrivals in Eastern Indonesia in 2010 was 251,669 people then increased in 2017 to $1,129,920$ people, with an average growth of $29.61 \%$ per year (BPS, 2018).

In the perspective of the empirical nexus between tourism development and economic growth have been widely examined, however, the empirical results generally produce diverse conclusions and often debated. Some researchers have found that tourism development has a positive impact on economic growth or supports the tourism led-growth hypothesis (TLGH). Other empirical studies have found a one-way relationship running from economic growth to the tourism sector that supports the economic driven tourism growth hypothesis or growth-led tourism hypothesis (GLTH). Several recent studies conducted in developed and developing countries have obtained empirical findings that support a two-way causality or there is a mutually influential relationship between tourism development and economic growth (bi-directional causality) that supports the feedback causality or reciprocal causal hypothesis while Kasimati (2011) and Katircioglu (2009) concluded that there was no causal relationship between tourism and economic growth or this argument supports the neutrality hypothesis. Çağlayan, Şak \& Karymshakov (2012) also revealed that there was no causal relationship between tourism and economic growth in the case of Asia, the Middle East and North Africa, Central Asia and Sub Saharan Africa.

The first empirical finding reveals that economic growth is determined by tourism development which supports the tourism-led economic growth hypothesis (TLGH). Empirical studies that support this hypothesis using time series data (Suhel \& Bashir, 2017); (Adnan Hye \& Khan, 2013); (Kibara, Odhiambo, \& Njuguna, 2012); (Akinboade \& Braimoh, 2010); (Kreishan, 2015); (Tang \& Tan, 2015); (Mishra, Rout, \& Mohapatra, 2011), (Jalil, Mahmood \& Idrees, 2013); (Risso \& Brida, 2008); (Bento, 2016); and (Brida, Lanzilotta, \& Pizzolon, 2016). Others applying panel and crosssection data that supports this argument/hypothesis is carried out by Çağlayan, Şak \& Karymshakov, (2012); Lee \& Chang (2008); Atan \& Arslanturk (2012) and Sequeira \& Nunes (2008). Meanwhile, De Vita \& Kyaw (2017) and Lee \& Chang (2008) employed panel data for supporting the tourism-led growth hypothesis (TLGH).

The growth-led tourism hypothesis argues that economic growth affects tourism expansion (GLTH). The studies in line with this hypothesis were conducted by Oh (2005); Payne \& Mervar (2010); Odhiambo (2011); Suresh \& Senthilnathan (2014), meanwhile, the reciprocal causality relationship or the feedback hypothesis (FH) considers the causal linkage between economic growth and tourism expansion as a bidirectional causality, where the impetus for the two variables gives mutual benefits. An 
empirical study was conducted by Nizar (2015) in Indonesia finding that there was a bidirectional causality relationship between the development of the tourism sector and economic growth or supported the reciprocal causal hypothesis. Recognition of a causal relationship between economic growth and tourism expansion is very important because it can have beneficial implications for relevant policy decision making (Khalil, Kakar, \& Waliullah, 2007); (Dritsakis, 2004); (Shuaibu \& Oladayo, 2016); (Songling, Ishtiaq, \& Thanh, 2019); (Katircioglu, 2009); (Ongan \& Demiröz, 2005); (Lee \& Chang, 2008); (Kim, Chen, \& Jang, 2006); (Atan \& Arslanturk, 2012); (Seghir, Mostéfa, Abbes \& Zakarya, 2015); (Tugcu, 2014); (Apergis \& Payne, 2012); (Chou, 2013) and (Seetanah, 2011).

This study aims to, firstly, to investigate and analyze the dynamic relationship between tourism sector development and economic growth both in the short and long run. Secondly, to examine the direction of causality between tourism development and economic growth in Eastern Indonesia over the period 2010-2017. The rest of this paper proceeds as follows: Section 2 presents a review of relevant literature. Section 3 describes the research method consisting of an explanation of the data and variables used, specifications of the econometric model, testing data and PVECM analysis. Section 4 explains the results and discussion. Section 5 is the final section that contains conclusions and recommendations.

\section{LITERATURE REVIEW}

In the perspective of an empirical study of tourism development, many researchers have previously conducted studies/research on the pattern of causal relationships between economic growth and tourism development, however, empirical results tend to be diverse, leading to lengthy debates and consensus differences. The first empirical finding is economic growth is determined by tourism development which supports the tourism-led economic growth hypothesis (TLGH). The second empirical finding is that tourism growth is driven by economic growth or supports the growth-led tourism hypothesis, which considers economic growth to affect tourism expansion (GLTH). The third empirical finding, reciprocal causality, or supporting the reciprocal causal hypothesis, which considers the causal relationship between economic growth and tourism expansion to be bi-directional causality, where the impetus for the two variables gives mutual benefits.

Chiu \& Yeh (2017) examined the threshold effects of the tourism-led growth hypothesis based on cross-sectional data of 84 countries. The study investigated the nexus between tourism development and economic growth and finds a linear positive impact of international tourism receipts on economic growth, which confirms evidence of the tourism-led growth hypothesis. The study was conducted by Šimundić, Kuliš \& Šerić (2016) about tourism and economic growth in Latin America and the Caribbean. Total countries studied there are 33 countries with a period of time from 2000 to 2014. The study employed a dynamic panel data approach. Variable used are real GDP, GDP per capita, tourism growth per capita, government expenditure, investment, openness, human capital and stability political. The results obtained by all variables are significant and have a positive effect. The Results of this research showed the positive impact of tourism on economic growth supporting the tourism-led growth hypothesis.

De Vita \& Kyaw (2017) investigated the relationship between tourism specialization and economic growth while accounting for the tourism destination 
countries, defined in terms of financial system development. The study employed a system generalized methods-of-moments (SYS-GMM) estimation methodology to investigate this relationship for 129 countries over the period 1995-2011. The results of the study concluded that the relationship between tourism specialization and economic growth is found to be positive and significant for middle-countries and high-income countries as they appear to gain considerably more from tourism specialization than low-income countries.

Cárdenas-García, Sánchez-Rivero \& Pulido-Fernández (2015) examined whether tourism growth influences economic development in a panel of 144 countries. The study groups the countries into two groups based on their different socioeconomic structures such as level of income per capita, infrastructure, training, or instability of the economic activity. The first group of countries characterize countries that showed a higher value of the synthetic index of economic development in 1991, where it has been demonstrated that tourism growth has led to an improvement of the economic development. Narayan, Sharma \& Banningidadmath (2013) used panel data predictive regression modeling in the Pacific Island countries from 1985-2010 and found a unidirectional causal flow from tourism to growth.

Çağlayan, Sak \& Karymshakov (2012) found a unidirectional causality running from tourism to economic growth in a panel of 135 countries for East Asia, South Asia and Oceania; and a unidirectional causality running from economic growth to tourism in the case of countries in America and Latin America and the Caribbean. Kibara, Odhiambo, \& Njuguna (2012) used time-series data from Kenya and an ARDL-bounds testing approach to examine the linkages between tourism and economic growth in a multivariate setting with trade as an intermittent variable. The finding from the study was a unidirectional causal flow from tourism development to economic growth both in the long and short run. Sequiera \& Nunes (2008) also validated the tourism-led growth hypothesis in the case of multiple countries from 1980 to 2002 using panel regression. The study tested real per capita GDP, the ratio of tourist arrivals to population, tourism receipts as a percentage of exports and as a percentage of GDP and other variables. Although a unidirectional causal flow from tourism to economic growth is found in all countries, the study also finds a decreasing effect of tourism on economic growth in small countries.

Payne \& Mervar (2010) used the Toda-Yamamoto causality test for Croatia and also find a unidirectional causality flow from GDP to tourism receipts. Katircioglu, (2009) employed the bounds test for cointegration and Granger causality tests to investigate a long-run equilibrium relationship between tourism, trade and real income growth as well as the direction of causality for Cyprus. The study found that GDP Granger-causes tourist arrivals. Odhiambo (2011) employed ARDL bounds testing and finds that in the long run, it is economic growth that drives the development of the tourism sector in Tanzania. Suresh \& Senthilnathan (2014) examined the causal relationship between economic growth and tourism earning in Sri Lanka during 19772012 by employing Granger-causality tests using annual time series data. The results revealed that there was a unidirectional causality flow from economic growth to tourism earning.

The research was conducted by Nizar (2015) employing the VAR model concluded that the growth of tourism and economic growth have a reciprocal causal relationship. The impact of tourism (receipts) growth increase will accelerate economic 
growth while the increase of GDP growth will boost the increase of tourism growth in the short-run. Chow (2013) examined causal relationships between tourism spending and economic growth in 10 transition countries for the period 1988-2011. Using panel causality analysis, the results supported and consistent with the feedback hypothesis for four of the ten countries namely the Czech Republic, Poland, Estonia, and Hungary. Seetanah (2011) applied panel data on 19 island economies over the period 1990 to 2007 to explore the potential contribution of tourism on economic growth and development within the conventional augmented Solow growth model. The study employed GMM methods and found that tourism significantly contributes to economic growth. Granger causality analysis further reveals a bidirectional relationship between tourism and growth. Apergis \& Payne (2012) examined the causal relationship between tourism and economic growth for a panel of nine Caribbean countries over the period 1995-2007. The panel error correction model revealed bi-directional causality between tourism and economic growth in both the short run and the long run.

\section{METHODS}

\section{Data and variable}

The type of data used in this study is secondary data in the form of panel data, which includes 12 provinces in Eastern Indonesia namely 1) West Nusa Tenggara, 2) East Nusa Tenggara, 3) North Sulawesi, 4) Central Sulawesi, 5 ) South Sulawesi, 6) Southeast Sulawesi, 7) Gorontalo, 8) West Sulawesi, 9) Maluku, 10) North Maluku, 11) West Papua, 12) Papua. The research period is from 2010 to 2017. All data was taken from the Indonesian Central Statistics Agency (BPS) and the Indonesian Ministry of Tourism. In this study, tourism development has two variables as proxy that have been widely used in previous studies, namely the number of tourist arrivals (JW) and private investment in the tourism sector (IP), measured by the number of tourism business units. Economic growth reflects an increase in production output from year to year, measured by the Gross Regional Domestic Product (GRDP). Data processing, the transformation of variables into natural logarithms and estimation of the econometrics model using Microsoft Excel and EViews 10.

\section{The specification of the econometric model}

This study applies the quantitative method approach. Panel Vector Error Correction Model (PVECM) is employed to 1) investigate the short-run and long-run causality between tourism development and economic growth. 2) determine the direction of the causal relationship between tourism development and economic growth in the short-run and long-run. Panel Vector Error Correction Model (PVECM) is a restricted PVAR (panel vector auto-regression) designed for use with non-stationary series that are known to be cointegrated. The PVECM has cointegration relations built into the specification so that it restricts the long-run behavior of the endogenous variables to converge their cointegrating relationships while allowing for short-run adjustment dynamics (Engle and Granger, 1987). The cointegration term is known as the error correction term because a series of partial short-run adjustments make corrections to deviations to achieve long-run equilibrium gradually.

If the variables are cointegrated of the same order, then the valid error correction model exists between the three variables. The determination of cointegration relationship (cointegrated vector) that shows the presence of a long-term relationship 
between variables, causality (Rachev, Mittnik, Fabozzi, Focardi \& Jasic, 2007); (Gujarati \& Porter, 2009). In PVECM treats the three observed variables (LPE, LJW, and LIP) as endogenous variables and include the lag value of each variable on the right-hand side of the equation. In the panel data, the VECM model used is written as follows:

$$
\begin{aligned}
& \Delta L P E_{i t}=\alpha_{1}+\sum_{i=1}^{p} \beta_{11} \Delta L P E_{i t-1}+\sum_{i=1}^{q} \beta_{12} \Delta L J W_{i t-1}+\sum_{i=1}^{r} \beta_{13} \Delta L I P_{i t-1}+\lambda_{1} E C T_{i t-1}+\mu_{1 i t} \\
& \Delta L J W_{i t}=\alpha_{2}+\sum_{i=1}^{p} \beta_{21} \Delta L J W_{i t-1}+\sum_{i=1}^{q} \beta_{22} \Delta L P E_{i t-1}+\sum_{i=1}^{r} \beta_{23} \Delta L I P_{i t-1}+\lambda_{2} E C T_{i t-1}+\mu_{21 t} \\
& \Delta L I P_{i t}=\alpha_{3}+\sum_{i=1}^{p} \beta_{31} \Delta L I P_{i t-1}+\sum_{i=1}^{q} \beta_{32} \Delta L P E_{i t-1}+\sum_{i=1}^{r} \beta_{33} \Delta L J W_{i t-1}+\lambda_{3} E C T_{i t-1}+\mu_{3 i t}
\end{aligned}
$$

Where ECT is expressed as follows:

$$
E C T_{i t}=L P E_{i t}-\beta_{0}-\beta_{12} L J W_{i t}-\beta_{13} L I P_{i t} \text {. }
$$

LPE is economic growth variable, measured by the natural logarithm of the Gross Regional Domestic Product (million IDR). LJW is the natural logarithm of the number of foreign tourists arrival. LIP is a private investment in the tourism sector, using the natural logarithm of the tourism business number (unit) as a proxy. ECT is an error correction term, $t$ is time (the year 2010-2017) and $i$ is cross-section data (12 provinces in Eastern Indonesia).

In this model, the error correction term is placed on the right-hand side. In the long-run equilibrium, this term is equal to zero. However, if LJW, LPE and LIP deviate from the long-run equilibrium, the error correction term will not be equal to zero and each variable adjusts to partially restore the equilibrium relation. The coefficient measures the speed of adjustment of the ith endogenous variable towards the equilibrium.

\section{Testing data and PVECM}

PVECM analysis must go through the following stages/procedures:

\section{Panel unit root test.}

The unit root test is used to test whether panel data is stationary or not stationary. Stationary data will tend to approach the average value and fluctuate around the average value. Panel data is a combination of times series data and cross-section, so the stationary test phase needs to be done to see whether there is a unit root contained between variables, so that the relationship between variables becomes valid. If the panel data has a root unit, it is said that the data moves randomly (random walk). If the absolute value of statistics is greater than the critical value, the observed data shows stationary or reject the null hypothesis. In this study, the method of panel data unit root tests is Levin, Lin \& Chu t-test, ADF (Augmented Dickey-Fuller)-Fisher test and Philips-Perron (PP)-Fisher test. Levin, Lin \& Chu (2002) in Baltagi (2005) used the panel data unit root test by considering the following ADF specifications:

$$
D Y_{i t}=\alpha Y_{i t-1}+\sum_{j=1}^{p} \beta_{i t} D Y_{i t-j}+X_{i t} \delta+\varepsilon_{i t}
$$

Where $Y_{i t}=$ panel data. $D Y_{i t}=$ difference form of $Y_{i t .,} \alpha=p-1, p i=$ number of lags adjusted for first difference. $\varepsilon_{\mathrm{it}}=$ error term.

\section{Panel cointegration test}

The presence of a cointegration relationship indicates the existence of a causal relationship but does not show the direction of causality between the variables. 
Cointegration is a long-term relationship between variables, although not individually stationary, but the linear combination between these variables becomes stationary. The use of Panel VECM requires that there be at least 2 cointegrated variables. The method that can be used to test the cointegration is Kao Residual Cointegration Test (EngleGranger Based). Kao (1999) in Baltagi (2005) proposed an Augmented Dickey-Fuller (ADF) panel cointegration test in which cointegrating vectors are assumed to be homogeneous. Let ${ }^{\wedge} \mathrm{e}_{\mathrm{it}}$ be the estimated residual from the following regression:

$$
y_{i t}=\alpha_{i}+\beta x_{i t}+\varepsilon_{i t}
$$

The Kao test is based on a version of the ADF test on the residual $\left(\varepsilon_{i t}\right)$ of the auxiliary regression $\varepsilon_{i t}=\rho \varepsilon_{i t-1}+v_{i t}$, or on the augmented version of the pooled specification:

$$
\varepsilon_{i t}=\rho \varepsilon_{i t-1}+\sum_{j=1}^{p} \lambda j^{\Delta \varepsilon_{i t-j}}+v_{i t}
$$

The ADF test is applied to the estimated residual: where $\mathrm{p}$ is chosen so that the residual $\mathrm{v}_{\text {it }}$ are serially uncorrelated. The ADF test statistic is the usual t-statistic in the previous equation. The null hypothesis of no cointegration, the ADF test statistics can be written as:

$$
A D F=\frac{t_{A D F}+\left(\frac{\sqrt{6 N \hat{\sigma} v}}{2 \hat{\sigma} 0 v}\right.}{\sqrt{\left(\frac{\hat{\sigma}_{0 v}^{2}}{2 \hat{\sigma}_{v}^{2}}+\left(10 \hat{\sigma}_{0 v}^{2}\right)\right.}}
$$

Where $\hat{\sigma}_{v}^{2}=\Sigma_{\mu \varepsilon}-\Sigma_{\mu \varepsilon} \Sigma_{\varepsilon_{s}}^{1} \hat{\sigma}_{0 v}^{2}=\Omega_{\mu \varepsilon}-\Omega_{\mu \varepsilon} \Omega_{E_{v}}^{1} \Omega$ is the long-run covariance matrix and $\mathrm{t}_{A D F}$ is the t-statistic of in the ADF regression. Kao shows that the ADF test converges to a standard normal distribution $\mathrm{N}(0,1)$. The statistical value of Kao panel data cointegration test $(\mathrm{ADF})$, when compared with the t-statistic value at $5 \%$ or the Probability value. If the statistical value is greater than the critical value or the probability value is less than 0.05 , there is a long-run relationship in the variables.

\section{Wald Test/VEC Granger Causality}

The short-run causality is also tested using the Wald test. The Wald test computes a test statistic based on the unrestricted regression. The Wald statistic measures how close the unrestricted estimates come to satisfy the restrictions under the null hypothesis. If the restrictions are in fact true, then the unrestricted estimates should come close to satisfy the restrictions.

\section{RESULT AND DISCUSSION}

\section{Description and testing of data}

Based on the research objectives that have been stated previously, namely 1) Researching or investigating the direction of causality between the development of the tourism sector and economic growth in Eastern Indonesia. 2) Analyzing the dynamic relationship between the development of the tourism sector and economic growth in Eastern Indonesia both in the short-run and long-run. To answer two main objectives, this study employs the Panel Vector Error Correction Model (PVECM).

A description of the panel data containing the mean, median, maximum value, lowest value (minimum) and the number of observations, available in Table 1. On 
average, the number of foreign tourist visits during the period of 2010-2017 in 12 provinces of Eastern Indonesia was 55,314 people, with a maximum value of 604,823 people. Table 1 also explains that economic growth, measured by Gross Regional Domestic Product (GRDP) experienced a significant increase of an average of $6.48 \%$ per year or an average GRDP value of Rp. 68,290.03 billion, with a maximum value of Rp.288,909 billion and a minimum value of Rp.14,984 billion. During 2010-2017, the achievement of the amount of private investment was an average of 295 business units per year, with a maximum figure of 112 business units and a minimum number of 62 business units.

Table 1. Description of data

\begin{tabular}{lccc}
\hline \multirow{2}{*}{ Statistics } & \multicolumn{3}{c}{ Data/Variables } \\
\cline { 2 - 4 } Mean & JW & PE & IP \\
Median & 55314.15 & 68290.03 & 294.7292 \\
Maximum & 8649.000 & 54811.09 & 224.5000 \\
Minimum & 604823.1 & 288908.6 & 1211.000 \\
Std. Dev. & 10.00000 & 14983.91 & 62.00000 \\
Jarque-Bera & 111582.0 & 58277.24 & 211.9719 \\
Probability & 593.9090 & 114.4607 & 89.19167 \\
Sum & 0.000000 & 0.000000 & 0.000000 \\
Sum Sq. Dev. & 5310159. & 6555842. & 28294.00 \\
Observations & $1.18 \mathrm{E}+12$ & $3.23 \mathrm{E}+11$ & 4268549. \\
\hline
\end{tabular}

Table 1 also explains that data are not normally distributed with the statistical significance indicator Jarque-Bera statistically significant at alpha of 5\%. The number of cross-section units is 12 provinces in Eastern Indonesia (KTI) and the total timeseries is 8 years (2010-2017) so that a total of 96-panel data observations are obtained.

The econometric model which used to analyze the direction of causality between the development of the tourism sector and economic growth and to analyze the dynamic relationship of the development of the tourism sector and economic growth both in the short-run and long-run in Eastern Indonesia is the Panel Vector Error Correction Model (PVECM). The first requirement in using PVECM analysis is that the data used should be stationary and integrated. Therefore, in this section, the first step is testing data stationarity by employing the methods of Levin, Lin \& Chu (LLC), and Augmented Dickey-Fuller (ADF) -Fisher and Philip-Perron (PP)-Fisher as shown in Table 2.

Table 2. Unit root test/stationarity of panel data

\begin{tabular}{ccccccc}
\hline \multirow{2}{*}{ Variables } & \multicolumn{3}{c}{ Level } & \multicolumn{3}{c}{ First Difference } \\
\cline { 2 - 7 } & \multirow{2}{*}{ LLC } & ADF-Fisher & PP-Fisher & LLC & ADF-Fisher & PP-Fisher \\
\hline \multirow{2}{*}{ LPE } & 0.20897 & 11.2724 & 13.8480 & -10.3348 & 111.101 & 147.732 \\
& $(0.5828)$ & $(0.9869)$ & $(0.9500)$ & $(0.000)^{* * *}$ & $(0.000)^{* * *}$ & $(0.000)^{* * *}$ \\
\hline \multirow{2}{*}{ LJW } & -0.99656 & 15.3241 & 16.4411 & -13.7387 & 145.858 & 170.143 \\
& $(0.1595)$ & $(0.9109)$ & $(0.8715)$ & $(0.000)^{* * *}$ & $(0.000)^{* * *}$ & $(0.000)^{* * *}$ \\
\hline \multirow{2}{*}{ LIP } & 0.40310 & 9.49429 & 10.2133 & -12.0683 & 127.625 & 150.377 \\
& $(0.6566)$ & $(0.9963)$ & $(0.9936)$ & $(0.000)^{* * *}$ & $(0.000)^{* * *}$ & $(0.000)^{* * *}$ \\
\hline
\end{tabular}

Note: LLC=Levin, Lin \& Chu. ADF-Fisher= Augmented Dickey-Fuller-Fisher

PP-Fisher=Philips-Perron-Fisher

Statistical value in parentheses () is p-value. ***, **, * Significant at alpha $1 \%, 5 \%, 10 \%$. 
Table 2 provides important information on the unit root test for examining stationarity of panel data by employing several methods namely Levin, Lin \& ChuFisher, Augmented Dickey Fuller-Fisher, and Philips Perron-Fisher. Testing data in level shows that all variables tested (LPE, LJW, and LIP) are not stationary or fail to reject the null hypothesis (there is unit root) so that the differencing process is one of the solution to make data stationer. In the first difference data, all variables tested are significant at alpha $5 \%$ (p-value $<0.05$ ) or reject the null hypothesis indicate that all first difference variables are stationary or have no unit root in the same order. The next step in using PVECM analysis is to carry out a cointegration test with the aim of identifying the existence of a long-term relationship between variables in the model, using the Kao residual cointegration test method presented in Table 3.

Table 3. Kao residual cointegration test

\begin{tabular}{lcc}
\hline Method & t-statistic & P-value \\
\hline ADF & -4.713161 & 0.0000 \\
Residual Variance & 0.257042 & \\
HAC Variance & 0.188656 & \\
\hline Note: $* * *, * *, *=$ Significant at alpha $1 \%, 5 \%, 10 \%$. &
\end{tabular}

The cointegration test results in Table 3 provide information that the ADF statistical value of the Kao residual cointegration test is statistically significant at alpha of $5 \%$ or $p$-value $<0.05$, indicating there is a long-term relationship between variables in the model. The presence of a cointegration relationship indicates the existence of a causal relationship but does not show the direction of causality between the variables. Data or variables (LPE, LJW, and LIP) have passed the stages of unit root and cointegration testing which is a condition of using PVECM analysis. The next step is to estimate PVECM with the aim, firstly, to obtain important information regarding the direction of the causal relationship between tourism development and economic growth. Secondly, the dynamic relationship between tourism development and economic growth both in the short and long term. PVECM estimation results can be seen in Table 4.

Table 4. Summary of PVECM estimation results

\begin{tabular}{|c|c|c|c|}
\hline \multirow{2}{*}{$\begin{array}{l}\text { Independent } \\
\text { Variables }\end{array}$} & \multicolumn{3}{|c|}{ Dependent Variables } \\
\hline & $\triangle \mathrm{LPE}$ & $\Delta \mathrm{LJW}$ & $\Delta \mathrm{LIP}$ \\
\hline \multicolumn{4}{|c|}{ Long-Run Coefficient } \\
\hline LJW(-1) & $\begin{array}{l}1.190377 \\
(7.34849) * * *\end{array}$ & - & - \\
\hline LIP(-1) & $\begin{array}{c}-2.762038 \\
(-7.24611)^{* * *}\end{array}$ & - & - \\
\hline ECT & $\begin{array}{l}-0.197222 \\
(-1.82067)^{*}\end{array}$ & $\begin{array}{l}-1.675971 \\
(-6.14329)^{* * *}\end{array}$ & $\begin{array}{c}-0.244931 \\
(-2.02494)^{* * *}\end{array}$ \\
\hline \multicolumn{4}{|c|}{ Short-Run Coefficient } \\
\hline$\Delta \mathrm{LPE}(-1)$ & $\begin{array}{l}-0.170378 \\
(-0.67872)\end{array}$ & $\begin{array}{c}1.381343 \\
(2.18493)^{* * *}\end{array}$ & $\begin{array}{l}-0.117197 \\
(-0.57546)\end{array}$ \\
\hline$\triangle \mathrm{LPE}(-2)$ & $\begin{array}{l}-0.170918 \\
(-0.74810)\end{array}$ & $\begin{array}{l}-0.126206 \\
(-0.21934)\end{array}$ & $\begin{array}{c}0.463008 \\
(1.81490)^{*}\end{array}$ \\
\hline$\Delta \mathrm{LJW}(-1)$ & $\begin{array}{l}-0.079406 \\
(-0.85985)\end{array}$ & $\begin{array}{l}0.134482 \\
(0.57822)\end{array}$ & $\begin{array}{c}0.021002 \\
{[0.20367]}\end{array}$ \\
\hline$\Delta \mathrm{LJW}(-2)$ & $\begin{array}{l}0.031257 \\
(0.49259)\end{array}$ & $\begin{array}{l}0.134482 \\
(1.45165)\end{array}$ & $\begin{array}{c}0.008810 \\
(0.12434])^{* * *}\end{array}$ \\
\hline$\Delta \mathrm{LIP}(-1)$ & $\begin{array}{c}0.002340 \\
(0.00837)\end{array}$ & $\begin{array}{c}-2.114926 \\
(-3.00254)^{* * *}\end{array}$ & $\begin{array}{c}-0.799624 \\
{[-2.56043]^{* * *}}\end{array}$ \\
\hline$\Delta \mathrm{LIP}(-2)$ & $\begin{array}{l}0.210642 \\
(0.95811)\end{array}$ & $\begin{array}{c}-0.603899 \\
{[1.21957)}\end{array}$ & $\begin{array}{c}-0.446928 \\
(-1.82054)^{*}\end{array}$ \\
\hline
\end{tabular}


Based on the PVECM estimation results summarized in Table 4, demonstrating several important information that there is a long-term causality running from tourism development variables (LJW, LIP) to the economic growth variable (LPE) and also giving a strong evidence of the existence of a long-run causality running from economic growth to the tourism development (LJW \& LIP). In the long run, tourism development affects economic growth and the achievement of economic growth leads to expansion of the tourism sector (feedback causality). The existence of a two-way relationship (bidirectional causality) is shown by the ECT coefficient, which is negative and statistically significant at alpha $5 \%$ for all variables. The ECT coefficient shows the speed of adjustment or the process of correction from the short run to lead to equilibrium in the long run. The speed of adjustment from tourism development to economic growth is $19.72 \%$ annually. Table 4 also reports that the two tourism development variables in the short run do not significantly affect economic growth, however changes in economic growth is found to have a statistically significant effect on tourism development at alpha 5\%, so that in the short term there is only a one-way relations running from economic growth to tourism development.

The final procedure is to test for a short run causality using the Wald test as set out in Table 5. There is no evidence to support the short-run causality running from tourism development variables (LJW and LIP) to economic growth variable (LPE) or fail to reject the null hypothesis of the Wald test. However, the Wald test shows significant short-run linkage running from economic growth (LPE) and tourism investment (LIP) to the number of foreign tourist arrival (LJW).

Table 5. Wald test/VEC Granger causality

\begin{tabular}{lcccc}
\hline Dependent variable & $\begin{array}{c}\text { independent } \\
\text { variable }\end{array}$ & Value & df & p-value \\
\hline LPE & LJW & 1.554582 & 2 & 0.4596 \\
& LIP & 2.079326 & 2 & 0.3536 \\
\hline LJW & LPE & 6.864627 & 2 & $0.0042^{* * *}$ \\
& LIP & 12.12901 & 2 & $0.0023^{* * *}$ \\
\hline LIP & LPE & 4.555168 & 2 & 0.1025 \\
& LJW & 0.043806 & 2 & 0.9783 \\
\hline \multicolumn{2}{c}{ Note: $* * *, * * *=$ Significant at alpha 1\%, $\%$ \%, $10 \%$} &
\end{tabular}

In summary, the case of empirical studies in eastern Indonesia using PVECM reveals bi-directional causality in the long-run or supports the feedback hypothesis, which are in line with research conducted by several previous studies (Chow, 2013; Apergis \& Payne, 2012), while in the short run, this empirical study supports the growth-led tourism hypothesis, which reveals the reverse causality running from economic growth to tourism development. Several previous studies corroborate these findings. Study Payne \& Merva (2010) used the Toda-Yamamoto causality test for Croatia and find a unidirectional causality flow from GDP to tourism receipts. Katircioglu (2007) found that GDP Granger-causes tourist arrivals. In Suresh \& Senthilnathan (2014) examined the causal relationship between economic growth and tourism earning in Sri Lanka during 1977-2012 is examined by employing Grangercausality tests using annual time series data. The results reveal that there is unidirectional causality flow from economic growth to tourism earning. 


\section{CONCLUSIONS AND RECOMENDATIONS}

\section{Conclusions}

This empirical study can conclude several important findings related to the pattern of dynamic relationships and the direction of the relationship between tourism development and economic growth both in the long run and short run by using the Panel VECM, this empirical study found that there was a bi-directional causality between tourism development and economic growth in the long run which corroborated the feedback hypothesis. However, in the short run, empirical findings supported the growth-led tourism hypothesis (GLTH) which argues that the achievements of economic growth affect the expansion of tourism development. This condition is in line with the economic development of the provinces in eastern Indonesia which are still lagging behind compared to economic development in the western regions of Indonesia which directly or indirectly influences tourism development.

\section{Recommendations}

Regional governments in eastern Indonesia should focus on the development and improvement of public infrastructure, tourism infrastructure and the strengthening of tourism services that are based on regional leading tourism so that in the long run it will have an impact on improving the performance of the tourism sector and accelerating economic growth simultaneously. In further research, it is necessary to add several variables that further strengthen the results of this study, namely government spending on the tourism sector and regional revenues from the tourism sector, with a longer period.

\section{REFERENCES}

Adnan Hye, Q. M., \& Ali Khan, R. E. (2013). Tourism-Led Growth Hypothesis: A Case Study of Pakistan. Asia Pacific Journal of Tourism Research, 18(4) 303-313. https://doi.org/10.1080/10941665.2012.658412

Akinboade, O. A., \& Braimoh, L. A. (2010). International tourism and economic development in South Africa: A granger causality test. International Journal of Tourism Research, 12(2) 149-163. https://doi.org/10.1002/jtr.743

Apergis, N., \& Payne, J. E. (2012). Research note: Tourism and growth in the Caribbean - Evidence from a panel error correction model. Tourism Economics, 18(2) 449-456. https://doi.org/10.5367/te.2012.0119

Atan, S., \& Arslanturk, Y. (2012). Tourism and Economic Growth Nexus: An InputOutput Analysis in Turkey. Procedia - Social and Behavioral Sciences, 62, 952956. https://doi.org/10.1016/j.sbspro.2012.09.162

Baltagi, B.H. (2005). Econometric Analysis of Panel Data. 3rd Edition, John Wiley \& Sons Inc., New York

Bento, J. P. C. (2016). Tourism and economic growth in Portugal: an empirical investigation of causal links. Tourism \& Management Studies, 12(1) 164-171. https://doi.org/10.18089/tms.2016.12117

Brida, J. G., Lanzilotta, B., \& Pizzolon, F. (2016). Dynamic relationship between tourism and economic growth in MERCOSUR countries: A nonlinear approach based on asymmetric time series models. Economics Bulletin, 36(2) 879-894.

Çağlayan, E., Şak, N., \& Karymshakov (2012). Relationship Between Tourism And Economic Growth: A Panel Granger Causality Approach. Asian Economic and 
Financial Review, 2(5) 591-602.

Cárdenas-García, P. J., Sánchez-Rivero, M., \& Pulido-Fernández, J. I. (2015). Does Tourism Growth Influence Economic Development? Journal of Travel Research, 54(2) 206-221. https://doi.org/10.1177/0047287513514297

Chiu, Y. Bin, \& Yeh, L. T. (2017). The Threshold Effects of the Tourism-Led Growth Hypothesis: Evidence from a Cross-sectional Model. Journal of Travel Research, 56(5) 625-637. https://doi.org/10.1177/0047287516650938

Chou, M. C. (2013). Does tourism development promote economic growth in transition countries? A panel data analysis. Economic Modelling, 33, 226-232. https://doi.org/10.1016/j.econmod.2013.04.024

De Vita, G., \& Kyaw, K. S. (2017). Tourism Specialization, Absorptive Capacity, and Economic Growth. Journal of Travel Research, 56(4) 423-435. https://doi.org/10.1177/0047287516650042

Dritsakis, N. (2004). Tourism as a long-run economic growth factor: An empirical investigation for Greece using causality analysis. Tourism Economics, 10(3) 305316. https://doi.org/10.5367/0000000041895094

Gujarati, D. N., \& Porter, D. C. (2009). Basic Econometrics (5th ed.). McGraw Hill Inc., New York.

Jalil, A., Mahmood, T., \& Idrees, M. (2013). Tourism-growth nexus in Pakistan: Evidence from ARDL bounds tests. Economic Modelling, 35, 185-191. https://doi.org/10.1016/j.econmod.2013.06.034

Kasimati, E. (2011). Economic impact of tourism on greece's economy: Cointegration and causality anzlysis. International Research Journal of Finance and Economics, 79, 79-85.

Katircioglu, S. (2009). Tourism, trade and growth: The case of Cyprus. Applied Economics, 41(21) 2741-2750. https://doi.org/10.1080/00036840701335512

Katircioglu, S. T. (2009). Revisiting the tourism-led-growth hypothesis for Turkey using the bounds test and Johansen approach for cointegration. Tourism Management, 30(1) 17-20. https://doi.org/10.1016/j.tourman.2008.04.004

Khalil, S., Kakar, M. K., \& Waliullah. (2007). Role of tourism in economic growth: Empirical evidence from Pakistan economy. Pakistan Development Review, 46(4) 985-995.

Kibara, O. N., Odhiambo, N. M., \& Njuguna, J. M. (2012). Tourism And Economic Growth In Kenya: An Empirical Investigation. International Business \& Economics Research Journal (IBER), 11(5) 517-525. https://doi.org/10.19030/iber.v11i5.6970

Kim, H. J., Chen, M. H., \& Jang, S. C. S. (2006). Tourism expansion and economic development: The case of Taiwan. Tourism Management, 27(5) 925-933. https://doi.org/10.1016/j.tourman.2005.05.011

Kreishan, F. M. (2015). Empirical Study on Tourism and Economic Growth of Bahrain: An ARDL Bounds Testing Approach. International Journal of Economics and Finance, 7(11) 1-10. https://doi.org/10.5539/ijef.v7n11p1

Lee, C. C., \& Chang, C. P. (2008). Tourism development and economic growth: A closer look at panels. Tourism Management, 29(1) 180-192. https://doi.org/10.1016/j.tourman.2007.02.013

Mishra, P. K., Rout, H. B., \& Mohapatra, S. S. (2011). Causality between tourism and economic growth: Empirical evidence from India. European Journal of Social 
Sciences, 18(4) 518-527.

Narayan, P.K.; Sharma, S. \& Banningidadmath, D. (2013) Does tourism predict macroeconomic performance in Pacific Islands countries? Working Paper SWP 2013/03, Financial Econometric Series, School of Accounting, Business and Finance, Faculty of Business and Law, Deakin University Australia.

Nizar, M. A. (2015). Tourism Effect on Economic Growth in Indonesia. MPRA Paper, (65628).

Odhiambo, N. M. (2011). Tourism development and economic growth in Tanzania: Empirical evidence from the ARDL-bounds testing approach., Economic Computation and Economic Cybernetics Studies and Research, 15(96) 200-220.

Oh, C. O. (2005). The contribution of tourism development to economic growth in the Korean economy. Tourism Management, 26(1) 39-44. https://doi.org/10.1016/j.tourman.2003.09.014

Ongan, S., \& Demiröz, D. M. (2005). The contribution of tourism to the long-run Turkish economic growth. Ekonomicky Casopis, 53(9) 880-894.

Payne, J. E., \& Mervar, A. (2010). The tourism-growth nexus in Croatia. Tourism Economics, 16(4) 1089.

Rachev, S. T., Mittnik, S., Fabozzi, F. J., Focardi, S. M., \& Jasic, T. (2007). Financial Econometrics: From Basics to Advanced Modeling Techniques. New York: John Wiley \& Sons

Risso, W. A., \& Brida, J. G. (2008). The Contribution of Tourism to Economic Growth: An Empirical Analysis for the Case of Chile. European Journal of Tourism Research, 13(6) 1537-1542. https://doi.org/10.1074/mcp.O114.037879

Seetanah, B. (2011). Assessing the dynamic economic impact of tourism for island economies. Annals of Tourism Research, 38(1) 291-308. https://doi.org/10.1016/j.annals.2010.08.009

Seghir, G. M., Mostéfa, B., Abbes, S. M., \& Zakarya, G. Y. (2015). Tourism SpendingEconomic Growth Causality in 49 Countries: A Dynamic Panel Data Approach. Procedia Economics and Finance, 23, 1613-1623. https://doi.org/10.1016/s22125671(15)00402-5

Sequeira, T. N., \& Nunes, P. M. (2008). Does tourism influence economic growth? A dynamic panel data approachy. Applied Economics, 40(18) 2431-2441. https://doi.org/10.1080/00036840600949520

Shuaibu, M., \& Oladayo, P. T. (2016). Determinants of human capital development in Africa: a panel data analysis. Oeconomia Copernicana, 7(4), 523. https://doi.org/10.12775/oec.2016.030

Šimundić, B., Kuliš, Z., \& Šerić, N. (2016). Tourism And Economic Growth: An Evidence For Latin American And Caribbean Countries. Tourism \& Hospitality Industry 2016-Congress Proceedings , 457-469.

Songling, Y., Ishtiaq, M., \& Thanh, B. T. (2019). Tourism Industry and Economic Growth Nexus in Beijing, China. Economies, 7(1), 25. https://doi.org/10.3390/economies7010025

Suhel, S., \& Bashir, A. (2018). The role of tourism toward economic growth in the local economy. Economic Journal of Emerging Markets, 10(1), 32-39. https://doi.org/10.20885/ejem.vol10.iss1.art4

Suresh, J., \& Senthilnathan, S. (2014). Relationship between Tourism and Economic Growth in Sri Lanka. SSRN Electronic Journal. 
https://doi.org/10.2139/ssrn.2373931

Tang, C. F., \& Tan, E. C. (2015). Tourism-Led Growth Hypothesis in Malaysia: Evidence-Based Upon Regime Shift Cointegration and Time-Varying Granger Causality Techniques. Asia Pacific Journal of Tourism Research, 20, 1430-1450. https://doi.org/10.1080/10941665.2014.998247

Tugcu, C. T. (2014). Tourism and economic growth nexus revisited: A panel causality analysis for the case of the Mediterranean Region. Tourism Management, 42, 207-212. https://doi.org/10.1016/j.tourman.2013.12.007 